\title{
Sessile drop evaluation of high temperature copper/spinel and slag/spinel interactions
} \author{
Kim Verbeken $^{\mathrm{a}}$ \\ a: $\quad$ Ghent University - Department of Materials Science and Engineering \\ Technologiepark 903 \\ B-9052 Zwijnaarde (Ghent) - Belgium \\ b: $\quad$ Umicore R\&D \\ Kasteelstraat 7 \\ B-2250 Olen - Belgium \\ c: $\quad$ KU Leuven- Department of Materials Engineering \\ Kasteelpark Arenberg 44, bus 2450 \\ B-3001 Heverlee (Leuven) - Belgium
}

Evelien De Wilde ${ }^{a}$, Inge Bellemans ${ }^{a}$, Mieke Campforts ${ }^{b}$, Muxing Guo $^{c}$, Bart Blanpain ${ }^{c}$, Nele Moelans ${ }^{c}$,

\section{CORRESPONDING AUTHOR}

Evelien De Wilde

Ghent University - Department of Materials Science and Engineering

Technologiepark 903

B-9052 Zwijnaarde (Ghent) - Belgium

+32484775580

evelien.dewilde@gmail.com

\section{ABSTRACT}

Metal droplets sticking to spinel solids, present in metallurgical slag systems, play an important role in hindering the sedimentation of copper in slags. To understand this phenomenon, in the present study, the interaction between spinel particles with $\mathrm{Cu}$ on the one hand and with slag, on the other hand, are evaluated. A dedicated approach was applied, using an industrially relevant synthetic slag system ( $\mathrm{PbO}-\mathrm{FeO}-\mathrm{SiO}_{2}-\mathrm{CaO}-\mathrm{Al}_{2} \mathrm{O}_{3}-\mathrm{Cu}_{2} \mathrm{O}-\mathrm{ZnO}$ ), pure copper and $\mathrm{MgAl}_{2} \mathrm{O}_{4}$ substrates to represent the industrial slag, the entrained copper droplets and the spinel solids, respectively. Both the copper - $\mathrm{MgAl}_{2} \mathrm{O}_{4}$ and the slag - $\mathrm{MgAl}_{2} \mathrm{O}_{4}$ interaction were studied using sessile drop measurements, combined with an extensive microstructural analysis. Additionally, the time effect on the slag - $\mathrm{MgAl}_{2} \mathrm{O}_{4}$ interaction was studied using immersion experiments. Based on the experimental results, a mechanism is proposed to explain the different interactions.

\section{Introduction}

Slags play an essential role in pyrometallurgical processes, for the elimination of unwanted impurities or acting as collectors for specific groups of metals. Therefore, a decantation step is often used in pyrometallurgical processes, allowing the phase separation between matte or metal and slag. Although desirable, these phase separations are not perfect, therefore industrial copper plants suffer from metal losses in slags, which confines the overall metal recovery.[1] To minimize these metal losses and improve the efficiencies of the industrial plants, it is essential to determine the origin and mechanisms behind these metal losses. 
Based on extensive research performed on copper losses, it is currently well accepted that copper losses in slags are attributed to both mechanical entrainment of copper-containing droplets and chemical copper losses.[2-4] Chemical copper losses are caused by the dissolution of copper as sulphide and oxide for primary copper production and mainly in its oxide form for secondary copper production. This type of losses is intrinsic to pyrometallurgical processes and is determined by the thermodynamic parameters of the system such as the temperature, the composition of the slag and the matte phase[3, 5-7], the oxygen partial pressure $[3,5-7]$, the kinetics and the chemical activity of the metal[3].

Mechanically entrained copper is defined as entrapped or floating unsettled droplets. In primary copper production, both matte and metallic droplets occur, while in secondary copper production these losses are mainly under the form of metallic copper droplets. Mechanically entrained droplets are ascribed to a variety of causes. A first important cause is the dispersion of copper sulphide or copper, which precipitates due to a local change of the solubility in the slag, for example, in zones with a different oxygen partial pressure or a lower temperature due to inhomogeneity of the process.[8] A second important source is entrained metal, originating from gas-producing reactions dispersing metal into the slag. The resulting $\mathrm{SO}_{2}$ bubbles nucleate at the bottom of the furnace and can elevate a surface film of matte/metal to the slag above.[8-10] Mechanical losses can also occur from operational procedures typically performed in pyrometallurgical processes like tapping or charging. Mechanical entrainment during tapping can originate due to the rise of a denser layer, which can happen while flowing around obstructions in the vessel.[2] The physical dispersion of matte or metal into the slag by mixing can originate from several causes such as gas injections, pouring one phase into the other or turbulence.[2,11] The abovementioned sources have been examined profoundly and reported in literature. Additionally the penetration of metallic copper into refractory can lead to metal losses.[12] There is however a fifth possible cause of mechanically entrained metal droplets, namely the attachment of droplets to solids in the slag, which obstructs their decantation. In copper industry, these solids are often identified to have a spinel structure. Notwithstanding the fact that the phenomenon has been reported by Ip and Toguri [8] and Andrews[11], and was observed by De Wilde[13] so far limited industrial or experimental data concerning this phenomenon are reported in literature. A prerequisite to further improve the phase separation in pyrometallurgical processes is a better understanding of the interactions between the three different phases involved (metal droplet, solids and slag).

Different methodologies have been applied to study metal losses in slags. However, little attention has been given to the phenomenon of sticking droplets and more specifically to the spinel - copper and spinel - slag interactions. The wetting behaviour between metals and oxides has been studied frequently, as summarized by Eustathopoulos et al.[14]. In most cases, a distinction is made between reactive and non-reactive systems. Non-reactive systems reach equilibrium in less than 0.1 seconds for millimetre sized droplets while slower spreading kinetics are a strong indication of the presence of interfacial reactions.[15] With respect to the specific wettability of metals on spinel substrates, Kozlova et al.[16] and Fukami et al..[17] performed experimental studies on the wettability of iron on $\mathrm{MgAl}_{2} \mathrm{O}_{4}$ spinel substrates, but no data have been found on the wetting of copper on spinel substrates specifically.

Wettability between slags and spinels has been studied in the frame of the study of inclusion removal in steel refining on the one hand, and the effect of the slag attack on refractories on the other hand. Abdeyzdan et al. investigated the wettability of $\mathrm{CaO}-\mathrm{Al}_{2} \mathrm{O}_{3}-\mathrm{SiO}_{2}-\mathrm{MgO}$ slag on $\mathrm{MgAl}_{2} \mathrm{O}_{4}$ spinels, and concluded that the slag showed a fast decrease of the contact angle during the first seconds, after which a plateau is reached for longer times.[18] Even at shorter timescales, slag reaction and penetration was observed. Donald et al. studied the interactions between fayalite slags and synthetic spinels, representing refractory materials.[19] Interfacial reaction products and dissolution of various refractory compounds into the slags were observed. Tran et al. studied the wetting between magnesia spinel bonded refractory and slag, revealing the effect of the Fe-content in the slag and temperature.[20] Nevertheless, previous research focused on fayalite-type slags. Studies on the 
wetting behaviour between spinel and PbO-based slag have, to our knowledge, not been published before. Moreover the sessile drop technique was not used before to study the losses due to the attachment of copper droplets to spinel solids in a slag phase.

This present study focuses on the interaction between spinel substrates and slag or copper, respectively. In this research, $\mathrm{MgAl}_{2} \mathrm{O}_{4}$ was chosen to represent the spinel phase, as this is one of the most stable spinel powders. A synthetic industrially relevant $\mathrm{PbO}$ - based slag was used ( $\mathrm{PbO}-\mathrm{FeO}$ $\mathrm{SiO}_{2}-\mathrm{CaO}-\mathrm{Al}_{2} \mathrm{O}_{3}-\mathrm{Cu}_{2} \mathrm{O}-\mathrm{ZnO}$ ). The (dynamic) wetting behaviour of spinel/copper and spinel/slag has been investigated combined with a detailed microstructural analysis. In addition, the evolution in time of the interaction between spinel and slag has been studied as well by variation of the immersion time of spinel substrates in the slag.

\section{Experimental procedure}

\subsection{Sessile drop experiments}

\subsubsection{Production of the slag system}

The slag was produced by melting oxides of appropriate quantities. Therefore, an appropriate slag composition was selected to obtain a spinel saturated single phase slag based on thermodynamic calculations using FactSage 6.4 thermochemical package (FACT and FT Oxid database). The final targeted slag composition is shown in Table $1 . \mathrm{CaO}$ was added as limestone and $\mathrm{FeO}$ was added as a combination of metallic iron and hematite. $400 \mathrm{~g}$ of the targeted composition was weighed, mixed and transferred in an $\mathrm{Al}_{2} \mathrm{O}_{3}$ crucible $(270 \mathrm{ml})$. The $\mathrm{Al}_{2} \mathrm{O}_{3}$ crucible, surrounded by a protective SiC crucible, was heated in an inductive furnace (Indutherm, MU3000) up to a temperature of $800^{\circ} \mathrm{C}$, while a protective $\mathrm{N}_{2}$ atmosphere was established above the slag. At $800^{\circ} \mathrm{C}$, the $\mathrm{N}_{2}$ atmosphere is replaced by $\mathrm{CO} / a$ ir mixture with volume ratio 1 to 2.44 , corresponding to an oxygen partial pressure $\left(p_{O_{2}}\right)$ of $10^{-7}$ atm, with a total flow rate of $60 \mathrm{l} / \mathrm{h}$, which is kept constant during the remainder of the experiment. Subsequently, the slag is heated to $1200^{\circ} \mathrm{C}$ and kept $30 \mathrm{~min}$ in order to melt all components. $\mathrm{N}_{2}(60 \mathrm{l} / \mathrm{h})$ is bubbled through the slag in order to homogenize the slag. The induction furnace is kept for $150 \mathrm{~min}$ at $1200^{\circ} \mathrm{C}$. Subsequently, all slag is quenched using a cold sampling bar, which is directly quenched in water and dried in a dry chamber at $150^{\circ} \mathrm{C}$.

\begin{tabular}{cccccccc}
\hline & $\mathbf{Z n O}$ & $\mathrm{PbO}$ & $\mathbf{S i O}_{2}$ & $\mathbf{A l}_{2} \mathbf{O}_{3}$ & $\mathrm{Cu}$ & $\mathrm{CaO}$ & $\mathbf{F e O}$ \\
\hline $\mathbf{w t} \%$ & 6.49 & 39.33 & 13.76 & 7.25 & 3.93 & 9.83 & 19.41 \\
\hline \multicolumn{7}{l}{ Table 1 Targeted synthetic slag composition, chosen based on thermodynamic FactSage calculations }
\end{tabular}

A representative sample of the slag after equilibration was embedded in epoxy resin, ground and polished using $9 \mu \mathrm{m}$ and $3 \mu \mathrm{m}$ diamond pastes. The sample was analysed using light optical microscopy (Keyence VHX-S9OBE, LOM) and electron probe microanalysis, using the backscattered electron microscopy mode (BSE, EPMA, JEOL JXA-8530F). For the latter the sample is coated with a conducting carbon layer.

Subsequently the composition of the different phases is analysed using a fully quantitative EPMAWDS (JEOL JXA-8530F) system, applying an acceleration voltage of $15 \mathrm{kV}$ and a probe current of 15 nA. The oxygen content of the slag phase and spinel particles was not measured directly; instead the oxidation state of the element was selected a priori. Although both $\mathrm{Fe}^{2+}$ and $\mathrm{Fe}^{3+}$ can be present, for the sake of clarity, only ' $\mathrm{FeO}^{\prime}$ was shown to be present in both the slag phase and spinel phase. The composition of the copper alloy droplets in the slag system was measured in the elemental state.

\subsubsection{Spinel preparation}


The $\mathrm{MgAl}_{2} \mathrm{O}_{4}$ substrates were produced using spark plasma sintering equipment (SPS, type HP D25/1, FCT system Rauenstein, Germany, equipped with a $250 \mathrm{kN}$ uniaxial press), using the same procedure as already described in our previous work.[13, 21, 22] The $\mathrm{MgAl}_{2} \mathrm{O}_{4}$ powder (Sigma Aldrich, magnesium aluminate, spinel nano powder, $<50 \mathrm{~nm}$ particle size) was sintered at a temperature of $1300^{\circ} \mathrm{C}$ under a load of $60 \mathrm{MPa}$. The sintered spinel plates were subsequently annealed at $1000^{\circ} \mathrm{C}$ for three hours and in a final step polished to a mirror finish using $9 \mu \mathrm{m}, 3 \mu \mathrm{m}$ and $1 \mu \mathrm{m}$ diamond pastes. A Talsurf profilometer was used to determine the surface roughness. The roughness parameter has an average value of $0.19+/-0.08 \mu \mathrm{m}$. The spinel phase was confirmed by XRD analysis, while some additional small corundum peaks were present in the XRD spectrum as well. A more detailed description on the sintering process is given in our previous paper.[21]

\subsubsection{Sessile drop experiments}

\subsubsection{Confocal scanning laser microscopy sessile drop set-up}

The interaction between $\mathrm{MgAl}_{2} \mathrm{O}_{4}$ and copper or slag was studied using a confocal scanning laser microscopy set-up (Lasertec 1LM21- SVF17SP, CSLM) with an infrared heating furnace. The infrared heating furnace allows fast heating and cooling in a gastight ellipsoidal chamber in which a $1.5 \mathrm{~kW}$ halogen lamp is placed in the lower focus point and the observed sample is positioned in the second confocal point. For this, the ellipsoidal chamber is coated with $\mathrm{Au}$ to reflect the light from the halogen lamp to the sample. A programmable PID controller controls the temperature, read from a type B (Pt-Rh) thermocouple, which is integrated into the sample holder. As described in previous work $[21,23]$, an extra window is placed at the side of the heating chamber, combined with a camera (Ganz ZC-F1OC3), which is placed on the same height, allowing to monitor the sessile drop experiment. An oxygen gas analyser was installed in the gas outlet to monitor the $\mathrm{pO}_{2}$ (Cambridge sensotec LTD, Rapidox 2100).[22, 24]

\subsubsection{Sessile drop experiments}

Sessile drop experiments were performed using pure copper or slag droplets on $\mathrm{MgAl}_{2} \mathrm{O}_{4}$ substrates. The experiments were performed under a protective $\mathrm{Ar}$ atmosphere. (99.999\% pure, $\mathrm{O}_{2}<1 \mathrm{ppm}$ ) The $\mathrm{MgAl}_{2} \mathrm{O}_{4}$ substrate was cleaned ultrasonically in acetone. The copper was etched using a 1:1 $\mathrm{H}_{2} \mathrm{O}$ : $\mathrm{HCl}$ solution, to remove the outer copper oxide layer. The $\mathrm{MgAl}_{2} \mathrm{O}_{4}$ substrate was placed on the sample holder and levelled carefully. Subsequently copper or slag was placed on the substrate and the heating chamber was closed and flushed three times with Ar. The temperature was increased up to $300^{\circ} \mathrm{C}$, with a heating rate of $50^{\circ} \mathrm{C} / \mathrm{min}$. After $1 \mathrm{~min}$, the temperature was increased up to $900^{\circ} \mathrm{C}$, with a heating rate of $200^{\circ} \mathrm{C} / \mathrm{min}$. After $1 \mathrm{~min}$ at $900^{\circ} \mathrm{C}$, the temperature was again increased until $1250^{\circ} \mathrm{C}\left(200^{\circ} \mathrm{C} / \mathrm{min}\right)$, which was further maintained for $10 \mathrm{~min}$. Finally the sample was cooled down with a cooling rate of $500^{\circ} \mathrm{C} / \mathrm{min}$. The complete interaction between substrate and molten droplet was monitored. The contact angle was defined using the low bond axisymmetric drop shape analysis plug-in for the Image J software, which is based on the fitting of the Young-Laplace equation to the shape of the droplet.[25]

The average weights of slag and copper during the sessile drop experiments were $0.0175 \mathrm{~g}$ and $0.022 \mathrm{~g}$ respectively. Each experiment has been repeated multiple times to ensure the reproducibility of the observations. The $\mathrm{pO}_{2}$ value during the experiments was between $6.5 * 10^{-5}$ and $7.5 * 10^{-5} \mathrm{~atm}$.

The obtained sessile drop samples were embedded (Technovit 4000 powder and liquid), grinded until the cross section between the spinel substrate and copper or slag became visible and then polished using 9, 3 and $1 \mu \mathrm{m}$ diamond paste. Samples were analysed using LOM and BSE (EPMA). The latter was combined with WDS analysis (EPMA, acceleration voltage $=15 \mathrm{kV}$; probe current $=15 \mathrm{nA}$ ), in order to measure phase compositions, as explained in section 2.1.1. 


\subsection{Study of the time effect on the slag-spinel interaction}

\subsubsection{Experimental methodology}

$\mathrm{MgAl}_{2} \mathrm{O}_{4}$ substrates are immersed in the slag for certain interaction times. The spinel substrates are produced using the procedure described in section 2.1.1. Slag with a composition as shown in Table 1 was melted in an induction furnace under identical experimental conditions as described in section 2.1.1. Prior to immersion of the substrate in the slag, the substrate is heated in the hot zone of the furnace to avoid the slag from cooling down when it would be in direct contact with a cold substrate. Subsequently, the $\mathrm{MgAl}_{2} \mathrm{O}_{4}$ substrate is immersed in the slag for $10 \mathrm{~s}, 30 \mathrm{~s}, 1 \mathrm{~min}$ and $3 \mathrm{~min}$. Consequently, the substrate and the attached slag are quenched in water and dried in the dry chamber at $150^{\circ} \mathrm{C}$.

\subsubsection{Characterization and analysis}

After immersion in the slag and quenching, the $\mathrm{MgAl}_{2} \mathrm{O}_{4}$ substrates were embedded (Technovit 4000 powder and liquid), grinded until the interface between the $\mathrm{MgAl}_{2} \mathrm{O}_{4}$ substrate and the slag became visible and finally polished using 9, 3 and $1 \mu \mathrm{m}$ diamond paste. The resulting samples were analysed using LOM and BSE. WDS-line scans (EPMA) were performed on the interfaces of each sample, as specified in section 2.1.1. (acceleration voltage $=15 \mathrm{kV}$; probe current $=15 \mathrm{nA}$ )

\section{Results}

\subsection{Microstructural analysis of the equilibrated slag system}

The microstructure of the slag phase after 150 min equilibration (section 2.1.1), which is used for the sessile drop experiment and the immersion experiment, can be observed in Figure 1. Three phases are present: slag (SL), spinel (SP) and copper droplets (Cu-dr). Some of these droplets were sticking to spinel particles, as can be clearly seen in Figure 1-(b). The presence of these three phases is consistent with the results from thermodynamic FactSage calculations. WDS analysis has been performed on the present phases and the resulting values are given in Table 2. Additionally, the theoretical compositions, obtained from the preliminary FactSage calculations for the considered experimental conditions $\left(1200^{\circ} \mathrm{C}, \mathrm{pO}_{2}=10^{-7} \mathrm{~atm}\right.$; FTOxid and FactPS database) are also given in Table 2. The theoretical amount of $\mathrm{Fe}_{2} \mathrm{O}_{3}$ was recalculated as $\mathrm{FeO}$. A good similarity is observed between the predicted and obtained slag composition, however a lower amount of $\mathrm{Cu}_{2} \mathrm{O}$ is present. The latter can be attributed to the fact that there is still metallic copper present in our system under the form of small entrained metallic copper alloy droplets and a copper layer at the bottom of the crucible. Based on the Factsage calculations, no metallic copper would be expected. This dissimilarity can be attributed to the fact that Factsage assumes ideal mixing of all components, while within the experiment the copper settled down. Furthermore, it can be assumed that after three hours, no thermodynamic equilibrium was reached yet. The spinel solids result from the three spinel forming components in the slag, namely $\mathrm{Al}_{2} \mathrm{O}_{3}, \mathrm{FeO}$ and $\mathrm{ZnO}$ and consist out of two phases: an Al-rich spinel phase in the core (Al-SP) and an Fe-rich spinel phase at the border (Fe-SP), (Figure $1-(c)$ ). Some spinel particles completely consist of the Fe-rich spinel phase. Based on FactSage calculations, the Ferich spinel is the equilibrium phase at $1200^{\circ} \mathrm{C}$. As it is always the Fe-rich spinel phase which is in direct contact and equilibrium with the slag system, focus will be put on the Fe-rich spinel phase throughout this paper. 


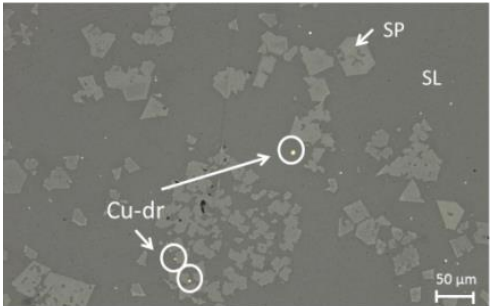

(a)

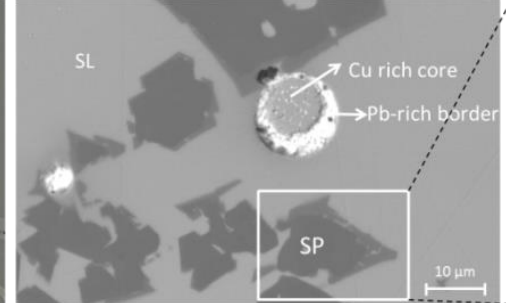

(b)

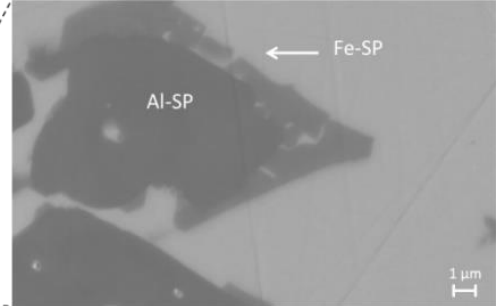

(c)

Figure 1 LOM (a) and BSE (b,c) images of the quenched slag obtained after $150 \mathrm{~min}$ equilibration. $(\mathrm{SP}=\mathrm{spinel}, \mathrm{SL}=\mathrm{slag}$, $\mathrm{Cu}-\mathrm{dr}=$ copper alloy droplets, AI-SP = Al-rich spinel phase, Fe-SP = Fe-rich spinel phase)

\begin{tabular}{cccccccc}
\hline wt\% & $\mathrm{Al}_{2} \mathrm{O}_{3}$ & ${ }^{\prime} \mathrm{FeO}$ & $\mathrm{Cu}_{2} \mathrm{O}$ & $\mathrm{CaO}$ & $\mathrm{ZnO}$ & $\mathrm{PbO}$ & $\mathrm{SiO}_{2}$ \\
\hline $\begin{array}{c}\text { Slag } \\
\text { (FactSage) }\end{array}$ & 7.1 & 13.6 & 4.8 & 10 & 5.8 & 42.8 & 15 \\
$\begin{array}{c}\text { Slag } \\
\text { Spinel }\end{array}$ & 7.1 & 16.1 & 1.3 & 8.7 & 5.5 & 36.4 & 25.7 \\
$\begin{array}{c}\text { (FactSage) } \\
\text { Al-rich } \\
\text { spinel }\end{array}$ & 14.2 & 74.4 & 0 & 0 & 11.34 & 0 & 0 \\
$\begin{array}{c}\text { Fe-rich } \\
\text { spinel }\end{array}$ & 17.7 & 63.6 & 0.1 & 0 & 14.3 & 0.3 & 0.4 \\
\hline
\end{tabular}

Table 2 WDS analysis of slag, Fe-rich spinel phase and Al-rich spinel phase and compositions of spinel and slag expected based on FactSage thermodynamic calculations

The WDS analysis of the copper alloy droplets is summarized in Table 3. For the present experimental conditions, these are $\mathrm{Cu}-\mathrm{Pb}$ droplets with a $\mathrm{Pb}$ rich border and a Cu-rich core, as indicated with arrows on Figure 1. This observation can be ascribed to the fact that quenching requires a certain, though limited, time which appears to be sufficient to induce a phase separation between $\mathrm{Cu}$ and $\mathrm{Pb}$, as a result of the very limited solubility of $\mathrm{Cu}$ and $\mathrm{Pb}$ at lower temperatures.

\begin{tabular}{cccccccc}
\hline wt\% & $\mathbf{O}$ & Al & Fe & Cu & Ca & Zn & Pb \\
\hline Cu core & 0.7 & 0 & 1.5 & 95 & 0 & 0.5 & 1.2 \\
$\begin{array}{l}\text { Pb-rich } \\
\text { border }\end{array}$ & 3.4 & 0 & 1.4 & 1.9 & 0.1 & 0.9 & 92.3 \\
\hline
\end{tabular}

Table 3 WDS analysis of Cu-rich core and the $\mathrm{Pb}$-rich border of the observed $\mathrm{Cu}-\mathrm{Pb}$ alloy droplets

\subsection{Spinel-copper interaction: sessile drop experiment}

\subsubsection{Wetting behaviour}

Figure 2 illustrates the wetting behaviour of copper on the $\mathrm{MgAl}_{2} \mathrm{O}_{4}$ substrate as a result of the heating of the materials to a temperature of $1250^{\circ} \mathrm{C}$ and keeping it at this temperature for $10 \mathrm{~min}$ under a protective argon atmosphere as described in section 2.1.3. The evolution of the contact angle as a function of time is presented in Figure 3. The start of copper melting was taken as the origin of the $\mathrm{x}$-axis, i.e. the time-scale. A clear non-wetting behaviour with a nearly constant contact angle is observed when the sample is kept at $1250^{\circ} \mathrm{C}$. These small variations in the measured contact angle are within the experimental error of the image analysis software program. 


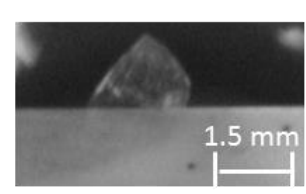

Before melt

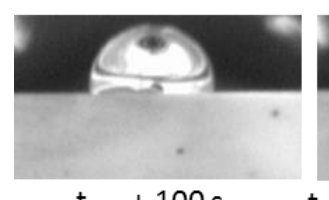

$t_{\text {melt }}+100 s$

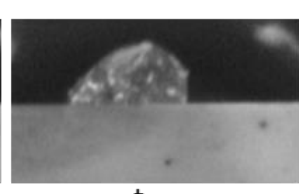

$t_{\text {melt }}$

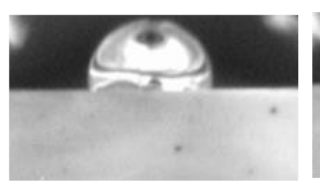

$t_{\text {melt }}+172 \mathrm{~s}-\mathrm{T}=1250^{\circ} \mathrm{C}$

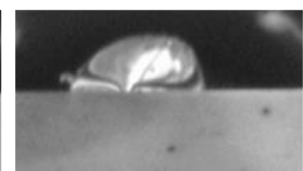

$t_{\text {melt }}+5 \mathrm{~s}$

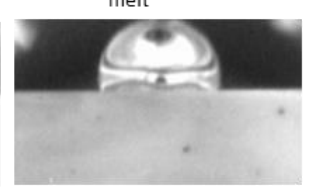

120 s at $1250^{\circ} \mathrm{C}$

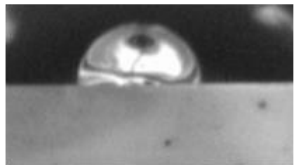

$t_{\text {melt }}+10 \mathrm{~s}$

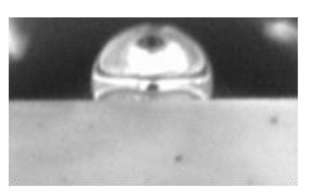

$240 \mathrm{~s}$ at $1250^{\circ} \mathrm{C}$

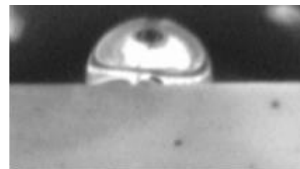

$t_{\text {melt }}+30 s$

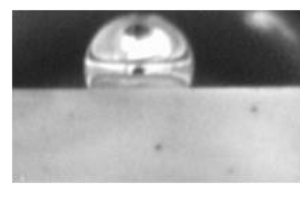

$480 \mathrm{~s}$ at $1250^{\circ} \mathrm{C}$

Figure 2 Melting and wetting behaviour of copper on $\mathrm{MgAl}_{2} \mathrm{O}_{4}$

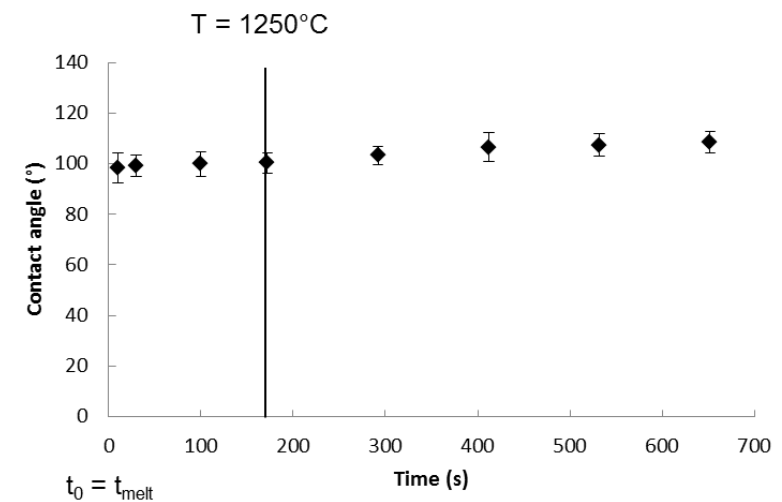

Figure 3 Evolution of the contact angle of a pure copper droplet on a $\mathrm{MgAl}_{2} \mathrm{O}_{4}$ substrate as a function of the interaction time. The start of copper melting was taken as the origin of the $x$-axis, i.e. the time scale $\left(t_{0}=t_{m e l t}\right)$

The cross-section of the copper droplet on the $\mathrm{MgAl}_{2} \mathrm{O}_{4}$ spinel is studied using BSE images and by WDS analysis. Based on the results no indications are found for chemical interactions occurring during the experiments

\subsection{Spinel-slag interaction}

\subsubsection{Sessile drop experiment $\mathrm{MgAl}_{2} \mathrm{O}_{4}-$ slag}

\subsubsection{Wetting behaviour}

The wetting behaviour of the synthetic $\mathrm{PbO}$-based slag on the $\mathrm{MgAl}_{2} \mathrm{O}_{4}$ spinel substrate is illustrated in Figure 4. The start of slag-melting was taken as the origin of the $\mathrm{x}$-axis, i.e. the time-scale. After $100 \mathrm{~s}$, the molten slag obtains a droplet shape, and from that point on contact angles are determined. The corresponding evolution of the contact angle between the slag and the spinel substrate is shown in Figure 5. Directly after melting, the liquid drop spreads out on the substrate within minutes while the temperature is increasing up to $1250^{\circ} \mathrm{C}$. A clear significant decrease of the contact angle is observed. Once the maximum temperature is reached, no further significant changes in the contact angle are observed. 

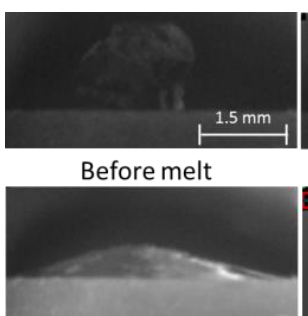

$\mathrm{T}_{\text {melt }}+180 \mathrm{~s}$
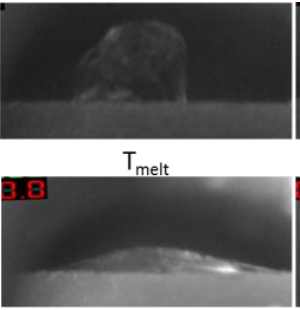

$\mathrm{T}_{\text {melt }}+283 \mathrm{~s}-\mathrm{T}=1250^{\circ} \mathrm{C}$

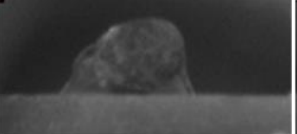

$\mathrm{T}_{\text {melt }}+60 \mathrm{~s}$

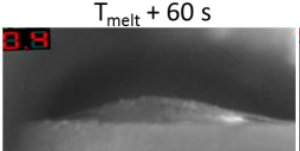

$200 \mathrm{~s}$ at $1250^{\circ} \mathrm{C}$

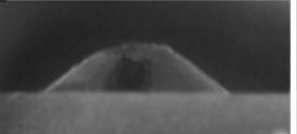

$\mathrm{T}_{\text {melt }}+90 \mathrm{~s}$

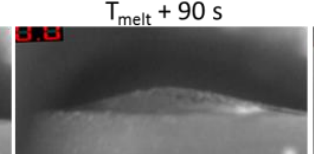

$400 \mathrm{~s}$ at $1250^{\circ} \mathrm{C}$

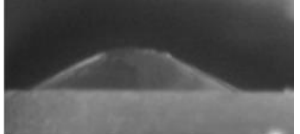

$\mathrm{T}_{\text {melt }}+120 \mathrm{~s}$

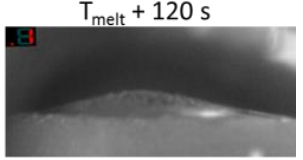

500 s at $1250^{\circ} \mathrm{C}$

Figure 4 Melting and wetting behaviour of the synthetic $\mathrm{PbO}-\mathrm{FeO}-\mathrm{SiO}_{2}-\mathrm{CaO}-\mathrm{Al}_{2} \mathrm{O}_{3}-\mathrm{Cu}_{2} \mathrm{O}-\mathrm{ZnO}$ slag on a $\mathrm{MgAl}_{2} \mathrm{O}_{4}$ substrate

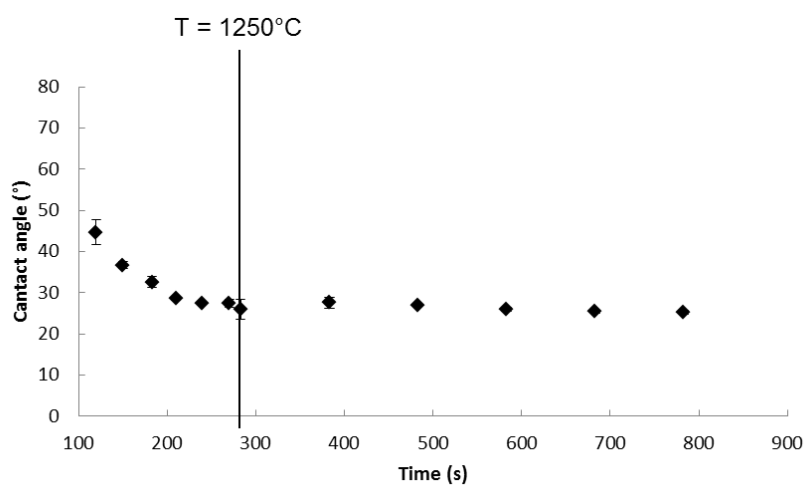

Figure 5 Evolution of the contact angle between the slag and the $\mathrm{MgAl}_{2} \mathrm{O}_{4}$ substrate as a function of the interaction time The start of slag-melting was taken as the origin of the $x$-axis, i.e. the time scale $\left(t_{0}=t_{\text {melt }}\right)$. As the slag obtained a droplet shape after $100 \mathrm{~s}$, contact angle are plotted starting from that point.

\subsubsection{Microstructural analysis}

Figure 6 shows the microstructure of the complete cross-section of the slag-spinel sessile drop sample. Based on the microstructure, the cross-section can be roughly subdivided into four different zones as indicated on Figure 6: (a) the $\mathrm{MgAl}_{2} \mathrm{O}_{4}$ substrate (b) an interaction layer at the slag- $\mathrm{MgAl}_{2} \mathrm{O}_{4}$ interface (c) a lower slag layer containing smaller spinel particles and very small black solids, marked with white circles and (d) the upper slag layer containing larger spinel particles, with a similar microstructure as the slag before the sessile drop experiment. The characteristics of each layer will be investigated in more detail in this section.

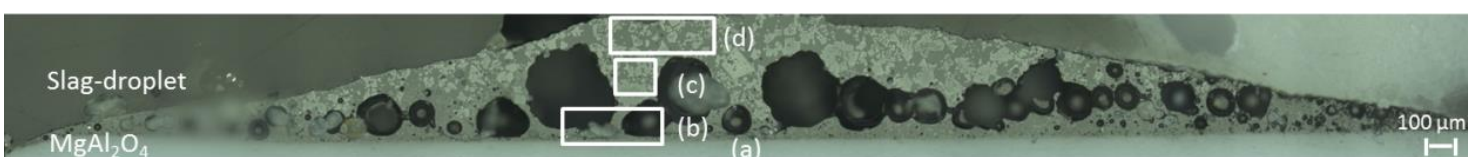

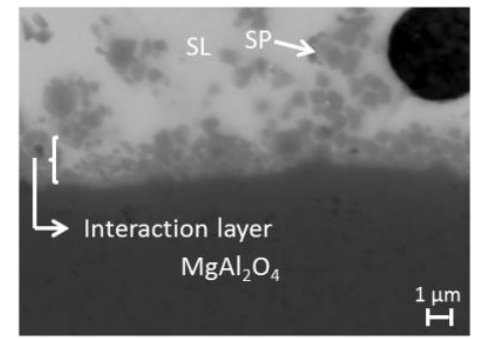

(b)

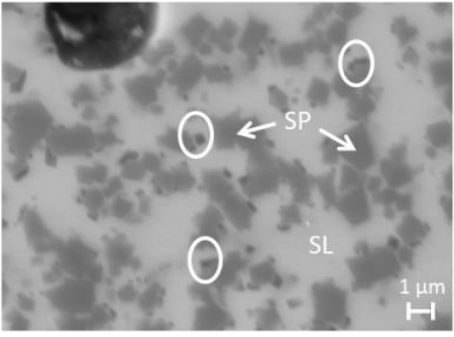

(c)

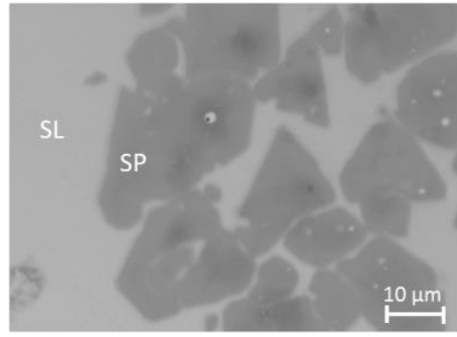

(d)

Figure 6 General overview of the complete cross-section between slag and $\mathrm{MgAl}_{2} \mathrm{O}_{4}$ substrate obtained by LOM, with subdivision in four different zones: (a) the $\mathrm{MgAl}_{2} \mathrm{O}_{4}$ substrate (a) the interaction layer at the slag- $\mathrm{MgAl}_{2} \mathrm{O}_{4}$ interface (b) a lower slag layer containing very small black solids marked with white circles (c) upper slag layer containing bigger spinel particles. $(\mathrm{SL}=$ slag, $\mathrm{SP}=$ spinel $)$ 
A detailed image of the interface between the spinel substrate and the slag droplet (zone b) is shown in Figure 7. A WDS-mapping of all present elements in the same area is shown in Figure 8. The formation of a clear interaction layer along the interface can be observed. This interaction layer consists of a very dense layer close to the spinel substrate which evolves to a layer of densely packed spinel particles with slag in between, further away from the spinel substrate, as indicated on Figure 7.

Quantitative WDS analysis is performed by EPMA, and the results are summarized in Table 4 . The interaction layer of the slag, near the slag/spinel interface was determined to be $(\mathrm{Mg}, \mathrm{Fe}, \mathrm{Zn})(\mathrm{Al}, \mathrm{Fe})_{2} \mathrm{O}_{4}$ and consisted mainly of $\mathrm{Al}_{2} \mathrm{O}_{3}$ and $\mathrm{MgO}$, combined with $\mathrm{ZnO}, \mathrm{Fe}_{2} \mathrm{O}_{3}$ and $\mathrm{FeO}$ present in the slag. The composition varies through the interaction layer, which is seen in the elemental $\mathrm{Fe}, \mathrm{Zn}, \mathrm{Mg}$ and $\mathrm{Al}$ mappings (Figure 8). Close to the spinel substrate $\mathrm{Mg}$ and $\mathrm{Al}$ are dominant, while closer to the slag phase the spinel forming elements $(\mathrm{Fe}, \mathrm{Zn})$ present in the slag become more prominent. On the elemental mappings of $\mathrm{Fe}$ and $\mathrm{Zn}$, it seems that $\mathrm{Fe}$ and $\mathrm{Zn}$ are diffused into the upper layer of the $\mathrm{MgAl}_{2} \mathrm{O}_{4}$ substrate. However, the gradients in composition seen on the elemental maps could also be due to an interference with the interaction layer. No indications for diffusion of the main slag forming elements $(\mathrm{Pb}, \mathrm{Si}, \mathrm{Ca}, \mathrm{Cu})$ towards the spinel substrate are observed. The WDS analysis indicated a $5 \mathrm{wt} \%$ increase of $\mathrm{Al}_{2} \mathrm{O}_{3}$ present in the slag as compared to the slag-composition before the sessile drop experiment (Table 2), indicating that $\mathrm{Al}_{2} \mathrm{O}_{3}$ dissolution into the slag has taken place.

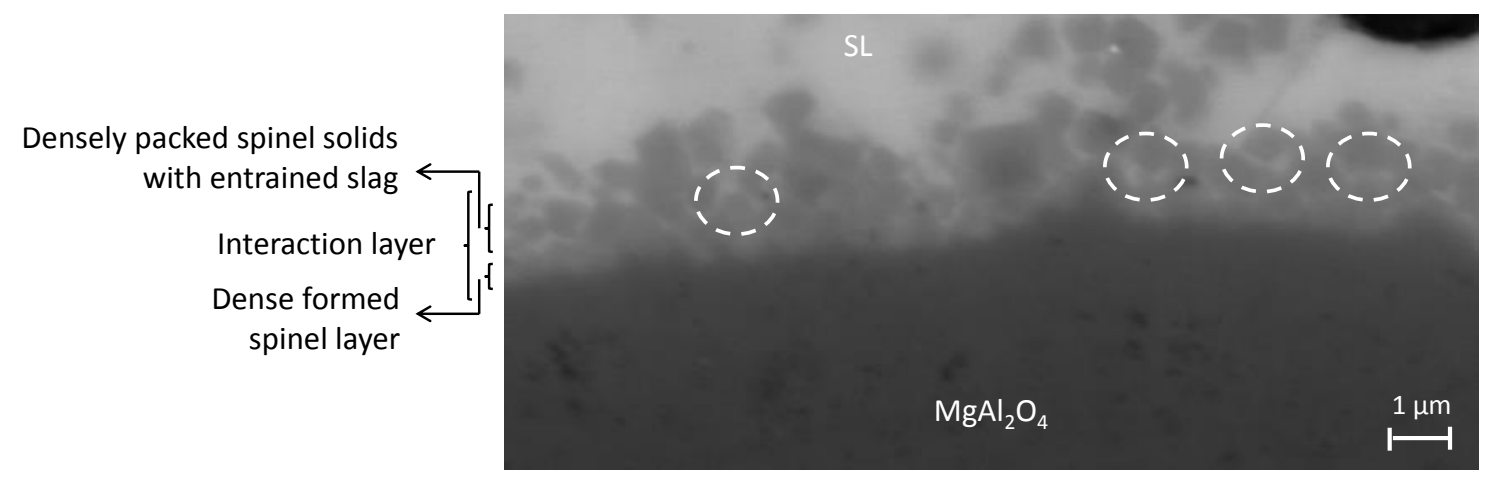

Figure 7 Detailed BSE image of the interaction layer at the $\mathrm{MgAl}_{2} \mathrm{O}_{4}$-slag interface in the sessile drop sample. This interaction layer can be roughly subdivided in two zones: a dense spinel layer next to the $\mathrm{MgAl}_{2} \mathrm{O}_{4}$ substrate and a densely packed layer of spinel solids with entrained slag on top $(S L=$ slag)

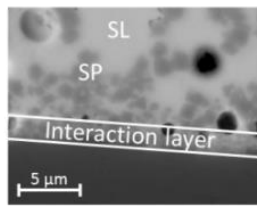

BSE

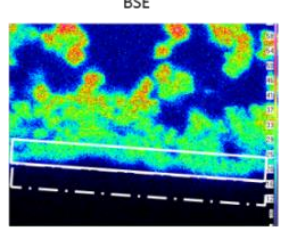

$\mathrm{Fe}$
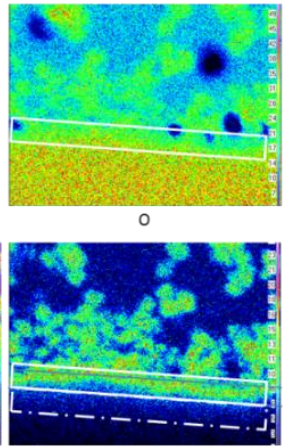

$\mathrm{Zn}$

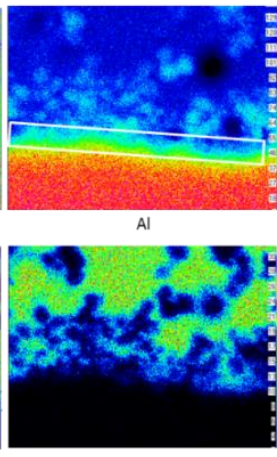

Si

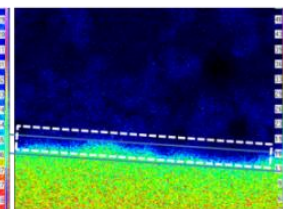

$\mathrm{Mg}$

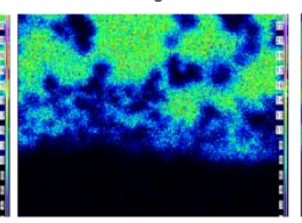

$\mathrm{Pb}$

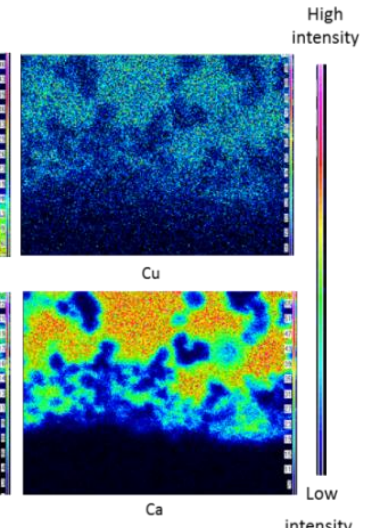

Ca

Figure 8 WDS elemental mapping of the slag- $\mathrm{MgAl}_{2} \mathrm{O}_{4}$ interface, indicating the presence of the interaction layer and a possible diffusion of $\mathrm{Zn}$ and $\mathrm{Fe}$ at the upper part of the $\mathrm{MgAl}_{2} \mathrm{O}_{4}$ substrate, indicated by the dotted frame $(\mathrm{SL}=\mathrm{slag}$, $\mathrm{SP}=$ spinel) 


\begin{tabular}{ccccccccc}
\hline $\mathbf{W t} \%$ & $\mathrm{Al}_{2} \mathrm{O}_{3}$ & $\mathbf{M g O}$ & ${ }^{\prime} \mathrm{FeO}$ & $\mathrm{Cu}_{2} \mathrm{O}$ & $\mathrm{CaO}$ & $\mathrm{ZnO}$ & $\mathrm{PbO}$ & $\mathrm{SiO}_{2}$ \\
\hline Upper part $\mathrm{MgAl}_{2} \mathrm{O}_{4}$ substrate & 74 & 22.4 & 0.52 & 0.1 & 0.8 & 0.8 & 0 & 0 \\
Interaction layer & 66.9 & 20.8 & 3.3 & 0.4 & 0.06 & 7.6 & 0.07 & 0.1 \\
Spinel solids in slag & 47.5 & 9.7 & 20.5 & 0.4 & 0.6 & 19.7 & 1.6 & 1.9 \\
Slag & 12.7 & 1.1 & 6.2 & 1.7 & 20.8 & 1.5 & 30.5 & 36.6 \\
\hline
\end{tabular}

Table 4 WDS analysis of the interaction layer, slag phase and spinel solids localised above the interface and the $\mathrm{MgAl}_{2} \mathrm{O}_{4}$ substrate close to the interface. (zone (b)) The listed compositions presented are an average value of points measured throughout the whole interface

Above the interaction layer, a lower slag layer containing small spinel solids is present, as shown in Figure $6-(c)$. EPMA- WDS analysis performed on the spinel solids and the slag phase are summarized in Table 5. The spinel solids consist of $\mathrm{Al}_{2} \mathrm{O}_{3}, \mathrm{MgO}, \mathrm{FeO}$ and $\mathrm{Fe}_{2} \mathrm{O}_{3}$. Compared to the spinel solids next to the interaction layer, the spinel solids in this zone are enriched in $\mathrm{FeO}-\mathrm{Fe}_{2} \mathrm{O}_{3}$ and depleted in $\mathrm{Al}_{2} \mathrm{O}_{3}$ and $\mathrm{MgO}$. Some very small black solids are present on the BSE image and seem to have formed on the spinel solids, as indicated on Figure 6. However, due to their very small size, no good elemental analysis was possible because of the interference with the surrounding slag phase and adjacent spinel solids.

\begin{tabular}{ccccccccc}
\hline $\mathbf{W t} \%$ & $\mathrm{Al}_{2} \mathrm{O}_{3}$ & $\mathrm{MgO}$ & ${ }^{\prime} \mathrm{FeO}$ & $\mathrm{Cu}_{2} \mathrm{O}$ & $\mathrm{CaO}$ & $\mathrm{ZnO}$ & $\mathrm{PbO}$ & $\mathrm{SiO}_{2}$ \\
\hline Slag & 13.7 & 1.3 & 6.6 & 1.7 & 10.6 & 1.7 & 29 & 35.4 \\
Spinel & 39 & 6.4 & 31 & 0.5 & 0.6 & 19.6 & 1.9 & 2.3 \\
\hline
\end{tabular}

Table 5 WDS analysis of the slag phase and spinel solids in the intermediate slag layer of the $\mathrm{MgAl}_{2} \mathrm{O}_{4}-$ slag sessile drop sample

At the upper part of the droplet, a slag phase is present with a similar microstructure as the unreacted slag system, described in section 3.1 (Figure 6 - (d)). Quantitative WDS analysis of the spinel particles and the slag are given in Table 6. The EPMA-WDS results indicate that the spinel solids have a similar composition as compared to the unreacted slag system (Table 2). The slag contains a smaller amount of $\mathrm{PbO}$ in comparison with the composition of the original slag system. This can be ascribed to the reduction of $\mathrm{PbO}$ to $\mathrm{Pb}$, followed by $\mathrm{Pb}$ evaporation.

\begin{tabular}{ccccccccc}
\hline $\mathbf{W t} \%$ & $\mathrm{Al}_{2} \mathrm{O}_{3}$ & $\mathrm{MgO}$ & ${ }^{2} \mathrm{FeO}$ & $\mathrm{Cu}_{2} \mathrm{O}$ & $\mathrm{CaO}$ & $\mathrm{ZnO}$ & $\mathrm{PbO}$ & $\mathrm{SiO}_{2}$ \\
\hline Slag & 12.37 & 0.5 & 8.1 & 1.49 & 11.5 & 2.7 & 29.1 & 36.1 \\
Spinel & 21.03 & 1 & 55 & 0.6 & 0 & 18.7 & 0 & 0.13 \\
\hline
\end{tabular}

Table 6 WDS analysis slag and spinel solids upper slag layer in the $\mathrm{MgAl}_{2} \mathrm{O}_{4}-$ slag sessile drop sample

\subsubsection{Influence interaction time on formation interaction layer $\mathrm{MgAl}_{2} \mathrm{O}_{4}-$ slag}

In the previous section, clear interaction between the spinel substrate and the slag was demonstrated. Therefore, in addition to the spinel-slag sessile drop experiment, the interaction between spinel and slag is studied by immersing a $\mathrm{MgAl}_{2} \mathrm{O}_{4}$ substrate for different interaction times into the produced synthetic slag. An overview of the slag $-\mathrm{MgAl}_{2} \mathrm{O}_{4}$ interface evolution with the interaction time is shown in Figure 9. Already after $10 \mathrm{~s}$, a clear interaction layer is formed, as indicated on Figure 9. This interaction layer grows with time. A steep increase in thickness of the interaction layer is noted during the first minutes while the increase in thickness between 1 and 3 min interaction time is limited. In the first stages (after $30 \mathrm{~s}$ ) an apparently quite dense interaction layer is formed. After $3 \mathrm{~min}$ the upper part of the interaction layer seems to evolve to a layer with densely packed spinel particles and slag in between the spinel particles, similarly to the interaction layer present in the spinel-slag sessile drop sample. (section 3.3.1.2). 
Increasing thickness of interaction layer

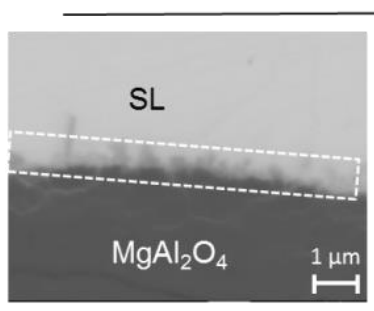

$10 \mathrm{~s}$

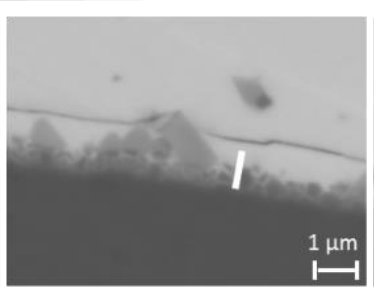

$30 \mathrm{~s}$

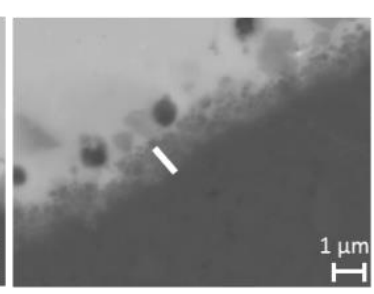

$1 \mathrm{~min}$

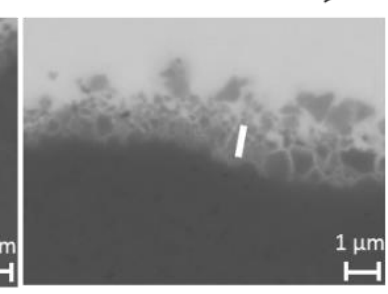

$3 \mathrm{~min}$

Figure $9 \mathrm{BSE}$ images illustrating the interaction between a $\mathrm{MgAl}_{2} \mathrm{O}_{4}$ substrate and slag after different interaction times. The white bars correspond to a distance of $1 \mu \mathrm{m}$ (SL = slag)

WDS-line scans for each element across the interface were measured for the spinel samples after 10 $\mathrm{s}, 30 \mathrm{~s}$ and $3 \mathrm{~min}$ in the slag phase. For each sample, the line-scans of the spinel forming elements $(\mathrm{O}$, $\mathrm{Al}, \mathrm{Zn}, \mathrm{Fe}, \mathrm{Mg}$ ) and the main slag forming components $(\mathrm{Ca}, \mathrm{Cu}, \mathrm{Pb}, \mathrm{Si})$ have been grouped for convenience of comparison.

After $10 \mathrm{~s}$, there is a delineated transition between the $\mathrm{MgAl}_{2} \mathrm{O}_{4}$ substrate and the slag phase. However, a slight enrichment of Fe could be noted at the interface, as indicated on Figure 9. This enrichment in Fe was confirmed by a WDS-mapping of this specific region of the sample.

The line-scans of the samples obtained after $30 \mathrm{~s}$ show a more gradual transition between the $\mathrm{MgAl}_{2} \mathrm{O}_{4}$ and the slag. Based on the line scans, three different zones are distinguished: the first zone is unaffected $\mathrm{MgAl}_{2} \mathrm{O}_{4}$. The second zone is the interaction layer between the slag and the spinel substrate. For convenience, the lines that demarcate the interaction layer are defined to between $90 \%$ and $20 \%$ of the amount of $\mathrm{Al}$ present in the $\mathrm{MgAl}_{2} \mathrm{O}_{4}$ substrate. The interaction layer consists mainly of spinel forming elements present in the substrate ( $\mathrm{Mg}$ and $\mathrm{Al}$ ) and the slag ( $\mathrm{Zn}, \mathrm{Fe}$ and $\mathrm{Al}$ ). Self-evidently, the higher $\mathrm{Mg}$ and $\mathrm{Al}$ concentrations are found closest to the spinel substrate, while higher amounts of $\mathrm{Fe}$ and $\mathrm{Zn}$ are present closer to the slag. The slag forming elements ( $\mathrm{Ca}, \mathrm{Cu}, \mathrm{Pb}$ and $\mathrm{Si}$ ) are also found in very low amounts gradually increasing when coming closer to the slag. Finally the third zone is the slag phase.

The line-scans after $3 \mathrm{~min}$ display the same three layers. The interaction layer has thickened due to the prolonged interaction time and can be roughly subdivided in two zones. On the one hand, next to the spinel substrate mainly spinel forming elements are present which give rise to the dense interaction layer next to the substrate. On the other hand, further away from the spinel substrate, both spinel forming elements and slag forming elements are present. This part of the interaction layer corresponds to the layer with densely packed spinel particles. Clearly there is a large similarity between the structure of the interaction layer formed after $3 \mathrm{~min}$ of immersion and that of the interaction layer present after the sessile drop experiment. (Figure 7) 


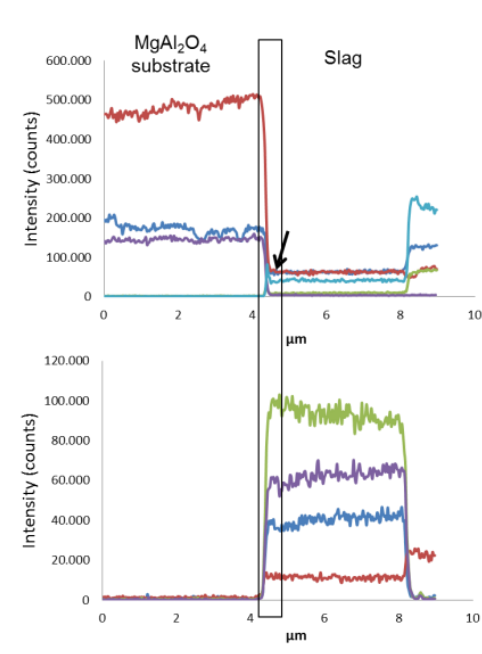

$10 \mathrm{~s}$

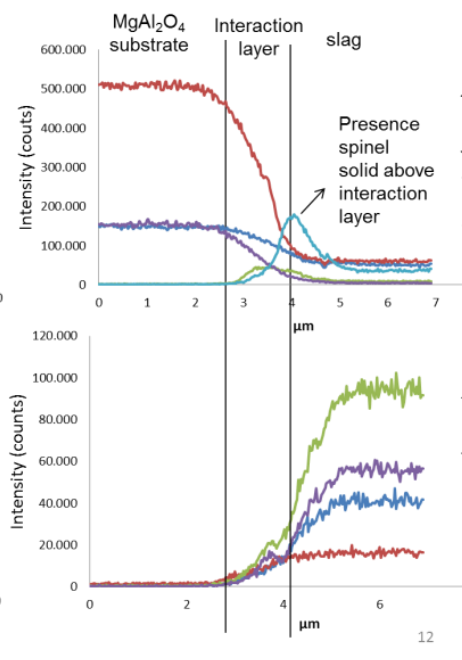

$30 \mathrm{~s}$

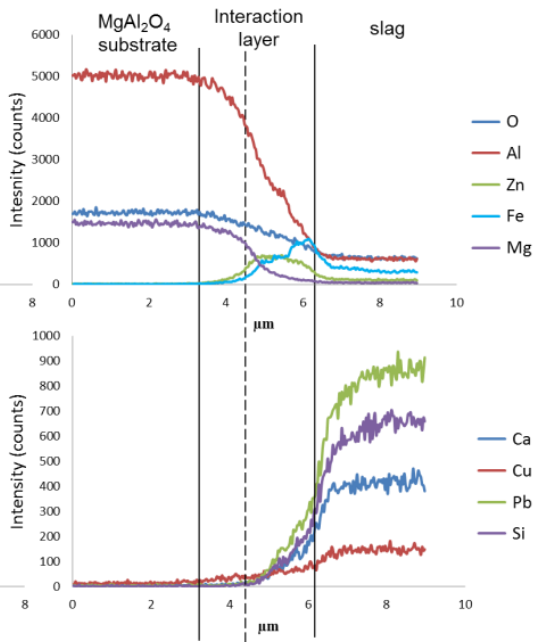

$3 \mathrm{~min}$

Figure 10 Elemental WDS line scans of slag- $\mathrm{MgAl}_{2} \mathrm{O}_{4}$ interface after interaction times of $10 \mathrm{~s}, 30 \mathrm{~s}$ and $3 \mathrm{~min}$. The upper graphs represent the compositional evolution at the interface for the spinel forming elements, the lower graphs show the evolution for the main slag forming elements.

\section{Discussion}

\section{1 $\mathrm{MgAl}_{2} \mathrm{O}_{4}-$ slag interaction}

The interaction between $\mathrm{MgAl}_{2} \mathrm{O}_{4}$ and slag has been studied in this work using two complementary experimental set-ups: a $\mathrm{MgAl}_{2} \mathrm{O}_{4}$-slag sessile drop experiment, studying the wetting behaviour, combined with a detailed microstructural investigation and by an immersion experiment of a spinel substrate in molten slag for different interaction times. In both experiments, a clear formation of an interaction layer at the interface of spinel and slag is observed.

Quantitative analysis of the interaction layer of the sessile drop sample demonstrated the presence of a $(\mathrm{Mg}, \mathrm{Fe}, \mathrm{Zn})(\mathrm{Al}, \mathrm{Fe})_{2} \mathrm{O}_{4}$ spinel-based interaction layer (Table 4) which consisted mainly of $\mathrm{Al}_{2} \mathrm{O}_{3}$ and $\mathrm{MgO}$, combined with some $\mathrm{ZnO}$ and ' $\mathrm{FeO}$ ' from the slag. Here and in the remainder discussion, ' $\mathrm{FeO}$ ' corresponds to both $\mathrm{FeO}$ and $\mathrm{Fe}_{2} \mathrm{O}_{3}$. A gradient in the composition of the interaction layer was observed in both the sessile drop (Figure 8 - WDS elemental mapping) and the immersion experiment (Figure $10-W D S$ line scan). Closer to the $\mathrm{MgAl}_{2} \mathrm{O}_{4}$ substrate, mainly $\mathrm{MgO}$ and $\mathrm{Al}_{2} \mathrm{O}_{3}$ were present while closer to the slag ' $\mathrm{FeO}$ ', $\mathrm{ZnO}$ and $\mathrm{Al}_{2} \mathrm{O}_{3}$ were observed. $\mathrm{Al}_{2} \mathrm{O}_{3}$ and $\mathrm{MgO}$, originating from the $\mathrm{MgAl}_{2} \mathrm{O}_{4}$ substrate, were liberated and dissolved in the slag.

$\mathrm{MgO}$ was present throughout the whole slag droplet, with a maximum concentration in the slag near the interaction layer at the $\mathrm{MgAl}_{2} \mathrm{O}_{4}$-slag interface. (cf. Table 4, Table 5 and Table 6) Furthermore, $\mathrm{MgO}$ was also partially incorporated in spinel particles in both the upper and lower slag layer. A significant increase of the $\mathrm{Al}_{2} \mathrm{O}_{3}$ content in the slag-phase in both the upper and lower slay layer compared to the unreacted slag is also observed, as stated in section 3.3.1.2.

Based on these observations, the following reaction is proposed to occur at the $\mathrm{MgAl}_{2} \mathrm{O}_{4}$-slag interface, which induces the formation of the observed interaction layer and causes the dissolution of $\mathrm{MgO}$ and $\mathrm{Al}_{2} \mathrm{O}_{3}$ in the slag:

$$
\begin{gathered}
\mathrm{MgAl}_{2} \mathrm{O}_{4(\mathrm{~s})}+\left(\mathrm{Fe}_{2} \mathrm{O}_{3}, \mathrm{FeO}, \mathrm{ZnO}, \mathrm{Al}_{2} \mathrm{O}_{3}\right)_{(\mathrm{l}, \text { in slag })} \rightarrow \\
\left(\mathrm{Mg}^{2+}, \mathrm{Fe}^{2+}, \mathrm{Zn}^{2+}\right)\left(\mathrm{Al}^{3+}, \mathrm{Fe}^{3+}\right)_{2} \mathrm{O}_{4}(\text { s, interaction layer }) \\
+\mathrm{MgO}_{\text {l,in slag }}+\mathrm{Al}_{2} \mathrm{O}_{3 \text { l,in slag }}
\end{gathered}
$$


A similar interaction between $\mathrm{MgAl}_{2} \mathrm{O}_{4}$ and fayalitic slag has been observed by Donald et al[19] :

$$
\mathrm{FeO}_{(\mathrm{l}, \text { in slag })}+\mathrm{MgAl}_{2} \mathrm{O}_{4(\mathrm{~s})} \rightarrow\left(\mathrm{Mg}_{\mathrm{x}}^{2+}, \mathrm{Fe}^{2+}\right) \mathrm{Al}_{2}^{3+} \mathrm{O}_{4}+\mathrm{Mg}_{1-\mathrm{x}} \mathrm{O}_{(\mathrm{l}, \text { in slag })}
$$

Thermodynamic analysis of the slag $-\mathrm{MgAl}_{2} \mathrm{O}_{4}$ system has also been carried out using the FactSage thermochemical package (Fact and FT oxid database) in order to verify the proposed reaction scheme. The interaction between $\mathrm{MgAl}_{2} \mathrm{O}_{4}$ and the used synthetic slag (Table 1) has been simulated for the experimental conditions of the sessile drop experiment $\left(1250^{\circ} \mathrm{C}, \mathrm{pO} 2=7.510^{-5} \mathrm{~atm}\right) .1 \mathrm{~g}$ of the targeted slag composition was taken as a starting point and different amounts of $\mathrm{MgAl}_{2} \mathrm{O}_{4}$ were added (up to $5 \mathrm{~g}$ ). This variation in the amount of $\mathrm{MgAl}_{2} \mathrm{O}_{4}$ was applied to evaluate the formation of the interaction layer, depending on the local availability of $\mathrm{MgO}$ and $\mathrm{Al}_{2} \mathrm{O}_{3}$ from the $\mathrm{MgAl}_{2} \mathrm{O}_{4}$ spinel substrate. Figure 11 represents the variations of the fraction of spinel and slag, as a function of the amount of added $\mathrm{MgAl}_{2} \mathrm{O}_{4}$. It can be observed that the addition of $\mathrm{MgAl}_{2} \mathrm{O}_{4}$ to slag generates more spinel in the system, which is likely to occur at the stag $-\mathrm{MgAl}_{2} \mathrm{\theta}_{4}$ interface resulting in an interaction layer. This indicates that there is a thermodynamic driving force for the formation of the interaction tayer.

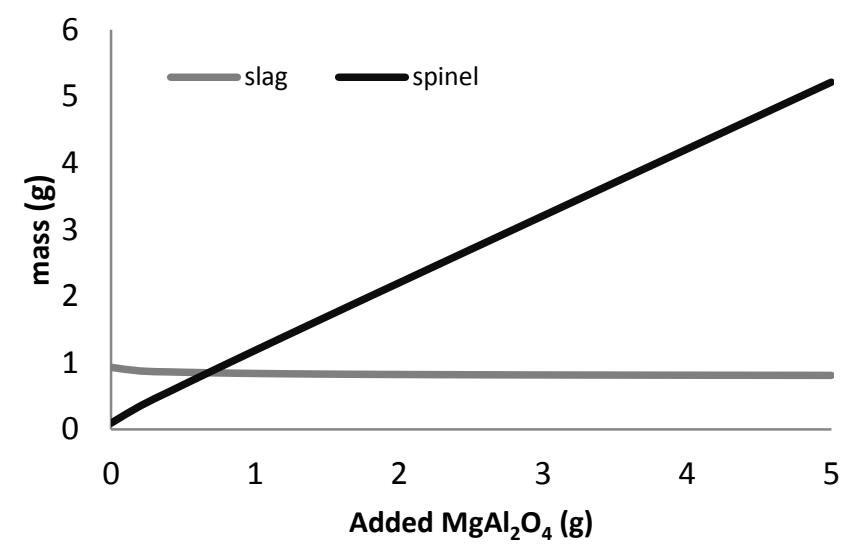

Figure 11 Results of the thermodynamic calculations, representing the influence of the addition of $\mathrm{MgAl}_{2} \mathrm{O}_{4}$ on the amount of spinel and slag

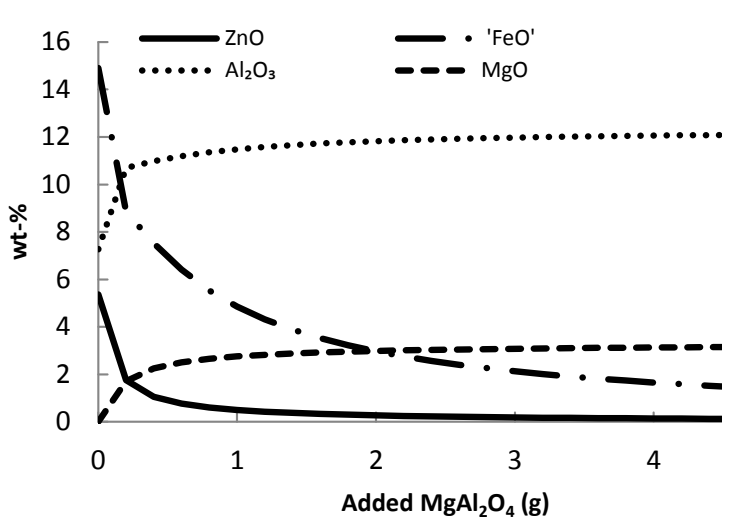

(a) Spinel

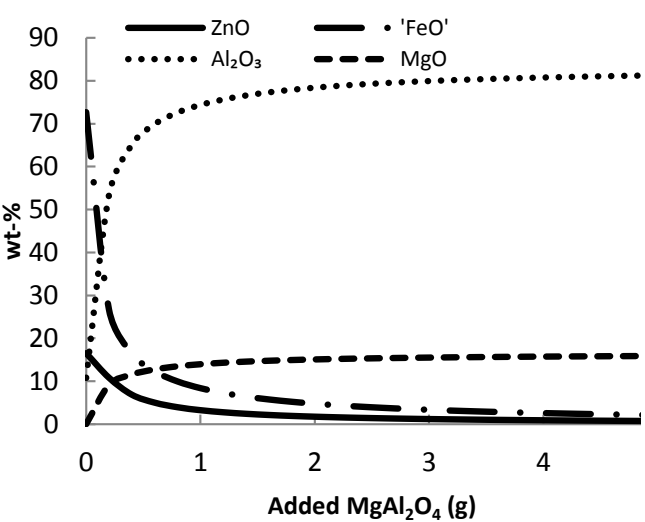

(b) Slag

Figure 12 Results of thermodynamic calculation by FactSage, representing the influence of the amount of $\mathrm{MgAl}_{2} \mathrm{O}_{4}$ on the composition of (a) the spinel particles and (b) the slag. ' $\mathrm{FeO}$ ' corresponds to both $\mathrm{FeO}$ and $\mathrm{Fe}_{2} \mathrm{O}_{3}$. An excess of slag refers to the fact that more slag than $\mathrm{MgAl}_{2} \mathrm{O}_{4}$ is present, an excess of $\mathrm{MgAl}_{2} \mathrm{O}_{4}$ refers to the fact that more $\mathrm{MgAl}_{2} \mathrm{O}_{4}$ than slag is present.

The composition of the formed spinel solids, and thus the interaction layer, depends on the local availability of $\mathrm{MgAl}_{2} \mathrm{O}_{4}$ as seen on Figure 12. An increase of the $\mathrm{MgAl}_{2} \mathrm{O}_{4}$ results in spinel solids with 
an increasing wt\% of $\mathrm{MgO}$ and $\mathrm{Al}_{2} \mathrm{O}_{3}$, which is found in the part of the interaction layer near the $\mathrm{MgAl}_{2} \mathrm{O}_{4}$ substrate in the experiments. When there is locally more slag present, ' $\mathrm{FeO}$ ' and $\mathrm{ZnO}$ will be more prominent in the formed spinel, which corresponds to the part of the interaction layer bordering on the slag liquid. These trends agree with the compositional variations throughout the formed interaction layers found in the experiment. The variation of the slag composition is presented in Figure 12- (b). The addition of $\mathrm{MgAl}_{2} \mathrm{O}_{4}$ results in an increase in the amount of $\mathrm{MgO}$ and $\mathrm{Al}_{2} \mathrm{O}_{3}$, as seen on Figure 12. This affirms the experimentally observed liberation of $\mathrm{MgO}$ and $\mathrm{Al}_{2} \mathrm{O}_{3}$ into the slag. It can be observed that the addition of $\mathrm{MgAl}_{2} \mathrm{O}_{4}$ to slag generates more spinel in the system, which is likely to occur at the slag $-\mathrm{MgAl}_{2} \mathrm{O}_{4}$ interface resulting in an interaction layer. This indicates that there is a thermodynamic driving force for the formation of the interaction layer.

As stated in the previous paragraph, the thermodynamic condition for the formation of an interaction layer is satisfied. It is assumed that the formation of this interaction layer occurs by nucleation and subsequent growth of the spinel particles.

Sandahge et al.[26] and Liu et al.[27] proposed a four-step nucleation model of spinel particles at the $\mathrm{MgO}-\mathrm{CaO}-\mathrm{SiO}_{2}-\mathrm{Al}_{2} \mathrm{O}_{3}$-(MgO) slag interface. Based on this model, it can be assumed that the nucleation of the spinel particles forming the interaction layer within our experimental systems involves a similar stepwise process: (1) the diffusion to and adsorption on the $\mathrm{MgAl}_{2} \mathrm{O}_{4}$ substrate of $\mathrm{Zn}, \mathrm{Fe}, \mathrm{Al}$ and O-bearing ions (2) the break-up of any complex ions that may be involved at the surface (3) surface diffusion of adsorbed ions and (4) collection of the critical concentration of $\mathrm{Zn}, \mathrm{Fe}$, $\mathrm{Al}, \mathrm{Mg}$ and oxygen ions at nucleation sites with subsequent formation of nuclei of spinel.[27] It was observed that the interaction layer was already present after $10 \mathrm{~s}$. (Figure 9) This indicates that this nucleation process must occur immediately after contact between the $\mathrm{MgAl}_{2} \mathrm{O}_{4}$ substrate and the slag.

The interaction layer displays a significant increase in thickness in the first minute. This fast formation rate of spinel particles has also been described before. Nightingale et al. [28] investigated the dissolution of $\mathrm{MgO}$ and simultaneous formation of $\mathrm{MgAl}_{2} \mathrm{O}_{4}$ spinel solids in a slag containing $\mathrm{CaO}$, $\mathrm{Al}_{2} \mathrm{O}_{3}$ and $\mathrm{SiO}_{2}$. The formation of spinel crystals was observed within seconds. Scheunis et al.[29] studied the interaction between magnesia-chromite refractories and a spinel saturated $\mathrm{PbO}$ nonferrous slag. The formation of a new $(\mathrm{Mg}, \mathrm{Fe})(\mathrm{Al}, \mathrm{Fe}, \mathrm{Cr})_{2} \mathrm{O}_{4}$ spinel layer at a growth rate of $290.5 \mu \mathrm{m}^{2} / \mathrm{h}$ was observed. The extent to which the initially formed nuclei can grow depends on the relative fluxes of the ' $\mathrm{FeO}$ ', $\mathrm{ZnO}, \mathrm{Al}_{2} \mathrm{O}_{3}$ from the slag towards the $\mathrm{MgAl}_{2} \mathrm{O}_{4}$ substrate and the fluxes of $\mathrm{MgO}$ and $\mathrm{Al}_{2} \mathrm{O}_{3}$ away from the $\mathrm{MgAl}_{2} \mathrm{O}_{4}$ substrate. Due to the formation of the interaction layer, the slag near this interaction layer becomes locally depleted in the spinel forming oxides, which have to diffuse from the surrounding slag to the interaction layer to enable further growth. Dissolution of $\mathrm{MgO}$ and $\mathrm{Al}_{2} \mathrm{O}_{3}$ from the spinel substrate into the slag is assumed to occur from the initial stage onwards, although it is inhibited by the formation of the interaction layer. If a continuous interaction layer is formed, $\mathrm{MgO}$ and $\mathrm{Al}_{2} \mathrm{O}_{3}$ originating from the $\mathrm{MgAl}_{2} \mathrm{O}_{4}$ substrate can continue to dissolve based on an indirect dissolution process, as described by Liu et al.[27]

Longer interaction times also result in a change in structure of the interaction layer, as seen on Figure 9. After $30 \mathrm{~s}$ the spinel layer consists of a very dense spinel layer, while after $1 \mathrm{~min}$ the upper part of the interaction layer consists of separate spinel particles which are densely packed. This can be on the one hand linked to the relatively lower spinel formation rate due to the depletion of the spinel forming elements. On the other hand it is also possible that some sort of dissociation occurs at the interaction layer - slag interface. [27]

Based on the experimental observations of the chemical processes occurring at the interface (equation (1)), the diffusion and dissolution of $\mathrm{MgO}$ and $\mathrm{Al}_{2} \mathrm{O}_{3}$ originating from the spinel substrate in the slag (section 3.3.1.2) and the nucleation and formation kinetics of the spinel, a schematic representation of the interaction layer formation at the $\mathrm{MgAl}_{2} \mathrm{O}_{4}$-slag interface for the applied system is proposed in Figure 13. For this purpose, the timing as observed during the immersion experiment was used. Hereby the interaction layer $\left((\mathrm{Mg}, \mathrm{Fe}, \mathrm{Zn})(\mathrm{Al}, \mathrm{Fe})_{2} \mathrm{O}_{4}\right)$ formed immediately from 
the first moment of contact between the $\mathrm{MgAl}_{2} \mathrm{O}_{4}$ spinel substrate and the slag. The interaction layer indeed nucleates and grows significantly in the first seconds, after which stagnation in the growth of the interaction layer is observed, probably due to a local depletion in spinel forming elements. This formation of the interaction layer was combined with the dissolution and diffusion of $\mathrm{MgO}$ and $\mathrm{Al}_{2} \mathrm{O}_{3}$ in the slag phase.

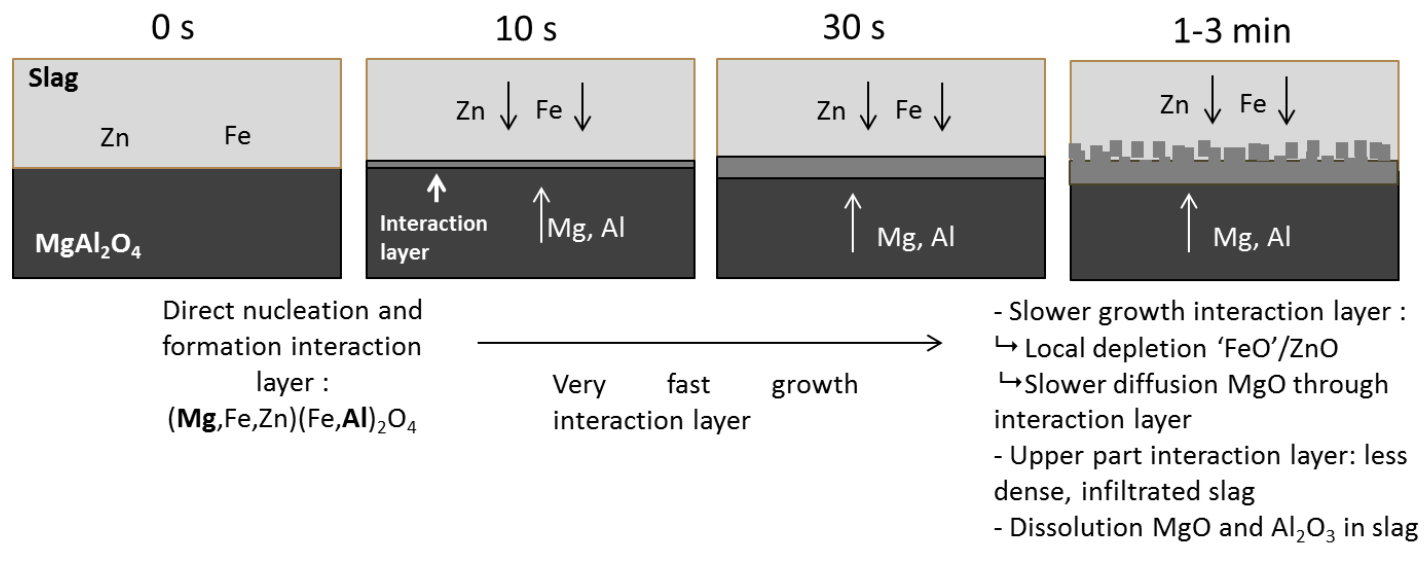

Figure 13 Proposed mechanism for the slag and $\mathrm{MgAl}_{2} \mathrm{O}_{4}$ interaction

\subsection{Comparison wetting behaviour copper and slag on spinel}

A significant difference is noted between the wetting behaviour of copper and slag on $\mathrm{MgAl}_{2} \mathrm{O}_{4}$. The synthetic slag displayed a very good wetting behaviour on $\mathrm{MgAl}_{2} \mathrm{O}_{4}$ (Figure 4, Figure 5), having big similarities with the kinetics of reactive wetting, as described by Eustathopoulos et al.[15] and the reactive wetting between $\mathrm{MgAl}_{2} \mathrm{O}_{4}$ and $\mathrm{CaO}-\mathrm{Al}_{2} \mathrm{O}_{3}-\mathrm{SiO}_{2}-\mathrm{MgO}$ slags as observed by Abdeyazdan et al.[18] Namely a rapid decrease of the contact angle at first, reaching a plateau after longer times. It should, however, be noted that both Eustatopoulos et al. and Abdeyazdan et al. add the slag on the substrate at high temperature, while in our set-up the droplet melts at lower temperature and then further heats together with the substrate. This difference in experimental set-up explains the difference in timescale with the results of Abdeyazdan et al., who observed a rapid decrease of the contact angle within $10 \mathrm{~s}$, as compared to $200 \mathrm{~s}$ in our slag- $\mathrm{MgAl}_{2} \mathrm{O}_{4}$ sessile drop experiment. The assumption of reactive wetting for the spinel-slag case was confirmed by microstructural analysis clearly showing the presence of an interaction layer. However, the decrease of the contact angle, shown in Figure 5, is therefore assumed to be mainly attributed to the reaction and not due to the increase in temperature.

By contrast, copper displayed a non-wetting behaviour, with an average contact angle of $103^{\circ}$. Based on the BSE image of the copper-spinel interface, no chemical interaction was noted between the two phases. Similar non-wetting behaviour between spinel particles and Cu-Ag alloys was observed for different oxygen partial pressures $\left(10^{-13}-10^{-8} \mathrm{~atm}\right)$ in our previous work.[13] The comparison between the wetting behaviour of copper on $\mathrm{MgAl}_{2} \mathrm{O}_{4}$ and $\mathrm{ZnFe}_{2} \mathrm{O}_{4}$ revealed a better wetting of the $\mathrm{ZnFe}_{2} \mathrm{O}_{4}$ substrate, indicating the importance, among others, of the chemical composition of the spinel substrate.[24] However, to our knowledge, no experimental data have been published, showing a comparable good wetting behaviour as slag on spinel. According to Eustathopoulus, the lowest experimental observed contact angle between magnetite and copper was around $60^{\circ}$, with an estimated oxide dissolution of $10^{-3}$ mole fraction in the liquid metal.

Based on the obtained results, it would be expected that a copper droplet would not be able to attach to a spinel solid which is surrounded by slag as the spinel-copper interfacial tension appears to be less beneficial than the spinel-slag interfacial tension, although sticking droplets are observed in industrial slags. However, attached droplets have been observed in our previous work. It has been 
derived that the attachment to spinel particles is energetically favourable if following condition is valid:[30]

$$
\gamma_{\mathrm{Sl}-\mathrm{Cu}}+\gamma_{\mathrm{Sp}-\mathrm{Sl}} \geq \gamma_{\mathrm{Sp}-\mathrm{Cu}}
$$

With $\gamma_{\mathrm{sl}-\mathrm{Cu}}$ the slag-copper interfacial tension, $\gamma_{\mathrm{sp}-\mathrm{sl}}$ the spinel-slag interfacial tension and $\gamma_{\mathrm{sp} \text {-cu }}$ the spinel-copper interfacial tension.

It is possible that the performed sessile drop experiments, making use of a protective argon atmosphere, are not representative for the system of sticking droplets in industrial or synthetic slag system. This can be attributed to a difference in the interfacial energies between the slag and copper droplets or spinel particles compared to the interfacial energies between argon and the copper droplet or $\mathrm{MgAl}_{2} \mathrm{O}_{4}$ substrate. However, the interactions at the spinel-slag interface, which are believed to be responsible for the good wettability observed in these experiments, will also take place in industrial slag systems. Thus, based on the current experiment, we can expect that the wetting of spinel by copper droplets is more difficult than the wetting of spinel by slag also in industrial slag systems.

With this it can be assumed that other mechanisms than interfacial tension most probably have an important role in the phenomenon of sticking droplets. The latter is enforced by observations in our previous work[30] and by phase field simulations performed by Bellemans et al.[31] They studied the attachment of metallic droplets to solid particles in liquid slags with a phase field model, in which the influence of particle characteristics (the particle density, perimeter, shape and distribution) were studied for systems of high and low wettability of the metallic phase. Based on the comparison of the modelled results and experimental results using the similar synthetic slag system as in this work, a low wettability system showed the best similarity, and thus the attachment is believed to partly originate from reactions between the metal, the slag and the solid particles. Based on experimental results in our previous work, similar conclusions were formulated.[30] However, more experimental research is necessary to give a decisive answer whether other mechanisms than interfacial tension are responsible for the occurrence of copper alloy droplets sticking to spinel particles.

\section{Conclusions}

In this work, the phenomenon of sticking copper alloy droplets to spinel solids in slags, hindering the sedimentation behaviour was studied. Focus was put specifically on the interaction between spinel and copper on the one hand and spinel and slag on the other hand. Both interactions have been studied using sessile drop measurements. For this purpose $\mathrm{MgAl}_{2} \mathrm{O}_{4}$ substrates, a synthetic slag (PbOFeO- $\mathrm{SiO}_{2}-\mathrm{CaO}-\mathrm{Al}_{2} \mathrm{O}_{3}-\mathrm{Cu}_{2} \mathrm{O}-\mathrm{ZnO}$ ) and pure copper were used to represent the spinel solids, the industrial slag and the entrained copper droplets respectively. In addition, the time influence on the $\mathrm{MgAl}_{2} \mathrm{O}_{4}$ - slag interaction was studied by immersion experiments.

Copper displayed a non-wetting behaviour on $\mathrm{MgAl}_{2} \mathrm{O}_{4}$, and no chemical interactions were observed between these phases. Slag, on the other hand, displayed a reactive wetting on $\mathrm{MgAl}_{2} \mathrm{O}_{4}$ substrates, and an interaction layer is formed at the interface. This interaction layer consisted of $(\mathrm{Mg}, \mathrm{Fe}, \mathrm{Zn})(\mathrm{Al}, \mathrm{Fe})_{2} \mathrm{O}_{4}$ spinel. Its nucleation and formation was very fast as indicated by samples with a $10 \mathrm{~s}$ interaction time. Subsequently, the formation speed lowered. Next to the formation of spinel layer, the diffusion of $\mathrm{MgO}$ and $\mathrm{Al}_{2} \mathrm{O}_{3}$ from the spinel substrate into the slag droplets was also noted.

Based on the current results showing that the wetting of slag on spinel is much better than the wetting of copper on spinel, it can be concluded that attached copper droplets are not stable or that there is at least a mechanical barrier of slag for copper droplets to overcome in order to attach to spinel solids present in the slag. Additionally, it is suggested that other processes, such as chemical 
reactions, probably play an important role in the origin of droplets sticking to spinel particles in the slags.

\section{Acknowledgments}

The authors wish to thank the agency for innovation by science and technology in Flanders (IWT, project 110541) and Umicore for its financial support and in particular Maurits van Camp, Luc Coeck, Saskia Bodvin, Kristel Van Ostaeyen, Eddy Boydens, Danny Leysen and the technical staff of Umicore R\&D for their support with the experiments and characterization. Pieter L'Hoëst is acknowledged for the help with the EPMA-WDS analysis and Joris Van Dyck and Jeroen Heulens for the help with the sessile drop experiments.

\section{References}

[1] DEGEL R., OTERDOOM H., KUNZE J., WARCZOK A., RIVEROS G. Latest results of the slag cleaning reactor for copper recovery and its potential for the PGM industry [C]//. Proc. Conf. Third international platinum conference 'Platinum in Transformation', Sun City, South Africa October 2008, Paper 7, 197-202.

[2] JONG-LENG L., JUUSELA M., GRAY N. B., SUTALO I. D. Entrainment of a two-layer liquid through a taphole [J]. Metallurgical and Materials Transactions B (Process Metallurgy and Materials Processing Science), 2003, 34B: 821-832.

[3] SUH I., WASEDA Y., YAZAWA A. Some interesting aspects of non-ferrous metallurgical slags [J]. High Temperature Materials and Processes, 1988, 8: 65-88.

[4] CARDONA N., HERNANDEZ L., ARANEDA E., PARRA R. Evaluation of copper losses in the slag cleaning circuits from two Chilean smelters [C]//. Proc. Conf. Copper 2010, Hamburg, Germany June 2010, Vol 7 Vol 7, 2637-2654.

[5] SRIDHAR R., TOGURI J., SIMEONOV S. Copper losses and thermodynamic considerations in copper smelting [J]. Metallurgical and Materials Transactions B, 1997, 28: 191-200.

[6] IMRIS I., SANCHEZ M. , ACHURRA G. Copper losses to slags obtained from the El Teniente process [C]//. Proc. 7th Int. Conf. on molten slags, fluxes and salts., Johannesburg, South Africa January 2004, 177-182.

[7] CARDONA N., COURSOL P., MACKEY P. J., PARRA R. Physical chemistry of copper smelting slags and copper losses at the Paipote smelter Part 1-Thermodynamic modelling [J]. Canadian Metallurgical Quarterly, 2011, 50: 318-329.

[8] IP S. W., TOGURI J. M. Entrainment behavior of copper and copper matte in copper smelting operations [J]. Metallurgical Transactions B-Process Metallurgy, 1992, 23: 303-311.

[9] MINTO R., DAVENPORT W.G. Entrapment and flotation of matte in molten slags [J]. Canadian Mining and Metallurgical Bulletin, 1972, 65: C36-42.

[10] MARU H. C., WASAN D. T., KINTNER R. C. Behavior of a rigid sphere at a liquid-liquid interface [J]. Chemical Engineering Science, 1971, 26: 1615-1628.

[11] ANDREWS LESLEY, in: Faculty of engineering, built environment and information technology, University of Pretoria, Pretoria, 2008, pp. 19-28.

[12] MALFLIET A., LOTFIAN S., SCHEUNIS L., PETKOV V., PANDELAERS L., JONES P. T., BLANPAIN B. Degradation mechanisms and use of refractory linings in copper production processes: A critical review [J]. Journal of the European Ceramic Society, 2014, 34: 849-876.

[13] DE WILDE E., BELLEMANS I., CAMPFORTS M., KHALIQ A., VANMEENSEL K., SEVENO D., GUO M., RHAMDHANI M., BROOKS G. A., BLANPAIN B., MOELANS N., VERBEKEN K. Wetting behaviour of Cu based alloys on spinel substrates in pyrometallurgical context [J]. Materials science and technology, 2015, In press 
[14] EUSTATHOPOULOS N., DREVET B. Determination of the nature of metal-oxide interfacial interactions from sessile drop data [J]. Materials Science and Engineering a-Structural Materials Properties Microstructure and Processing, 1998, 249: 176-183.

[15] EUSTATHOPOULOS N., NICHOLAS M.G., DREVET B. Wettability at high temperatures [M]. Oxford: Pergamon, 1999.

[16] KOZLOVA O. B., SUVOROV S. A. The wetting of refractories of the MgO-Al2O3-ZrO2 system with metal melts [J]. Refractories, 1976, 17: 763-767.

[17] FUKAMI Naotaka, WAKAMATSU Ryoheil, SHINOZAKI Nobuya, WASAI Kyoko. Wettability between Porous MgAl2O4 Substrates and Molten Iron [J]. Materials Transactions, 2009, 50: 2552-2556.

[18] ABDEYAZDAN H., DOGAN N., RHAMDHANI M., CHAPMAN M., MONAGHAN B. Dynamic wetting of $\mathrm{CaO}-\mathrm{Al} 2 \mathrm{O} 3-\mathrm{SiO} 2-\mathrm{MgO}$ liquid oxide on $\mathrm{MgAl} 2 \mathrm{O} 4$ spinel [J]. Metallurgical and Materials Transactions B - Process Metallurgy and Materials Processing Science, 2014, 46: 208-219.

[19] DONALD J. R., TOGURI J. M., DOYLE C. Surface interactions between fayalite slags and synthetic spinels and solid solutions [J]. Metallurgical and Materials Transactions B-Process Metallurgy and Materials Processing Science, 1998, 29: 317-323.

[20] TRAN T., XIE D., CHENG Y.B. Effects of slag chemistry and temperature on wetting and penetration of refractories by slags $[\mathrm{C}] / /$. VII international conference on molten slags fluxes and salts, 2004,

[21] DE WILDE Evelien, BELLEMANS Inge, VERVYNCKT Stephanie, CAMPFORTS Mieke, VANMEENSEL Kim, MOELANS Nele, VERBEKEN Kim. Towards a methology to study the interaction between $\mathrm{Cu}$ droplets and spinel particles in slags [C]//European Metallurgical Conference 2013, Weimar, 2013, 1: 161-174.

[22] DE WILDE Evelien, VERVYNCKT Stephanie, CAMPFORTS Mieke, GODIER Greetje, VANMEENSEL Kim, MOELANS Nele, VERBEKEN Kim. Characterization methodology for copper-droplet losses in slags [C]//. Copper conference 2013, Santiago, 2013, vol 3: 189-197.

[23] BELLEMANS Inge, Master dissertation: Materials Science and Engineering, Ghent University, Ghent, Belgium, 2013, pp. 184.

[24] DE WILDE E., BELLEMANS I., CAMPFORTS M., GUO M., VANMEENSEL K., BLANPAIN B., MOELANS N., VERBEKEN K. Wetting behaviour of spinel with copper to understand metallic copper losses to slags [C]//. European Metallurgical Conference, Düsseldorf, 2015, 1: 3-18.

[25] STALDER A. F., MELCHIOR T., MULLER M., SAGE D., BLU T., UNSER M. Low-bond axisymmetric drop shape analysis for surface tension and contact angle measurements of sessile drops [J]. Colloids and Surfaces a-Physicochemical and Engineering Aspects, 2010, 364: 72-81.

[26] SANDHAGE K. H., YUREK G. J. Indirect dissolution of sapphier into silicate metls [J]. Journal of the American Ceramic Society, 1988, 71: 478-489.

[27] LIU J., GUO M., JONES P. T., VERHAEGHE F., BLANPAIN B., WOLLANTS P. In situ observation of the direct and indirect dissolution of $\mathrm{MgO}$ particles in $\mathrm{CaO}-\mathrm{Al}$ 2O3-SiO2-based slags [J]. Journal of the European Ceramic Society, 2007, 27: 1961-1972.

[28] NIGHTINGALE S. A., MONAGHAN B. J. Kinetics of Spinel Formation and Growth during Dissolution of $\mathrm{MgO}$ in $\mathrm{CaO}-\mathrm{Al} 2 \mathrm{O} 3-\mathrm{SiO} 2$ Slag [J]. Metallurgical and Materials Transactions B-Process Metallurgy and Materials Processing Science, 2008, 39: 643-648.

[29] SCHEUNIS L., CAMPFORTS M., JONES P. T., BLANPAIN B., MALFLIET A. The influence of slag compositional changes on the chemical degradation of magnesia-chromite refractories exposed to $\mathrm{PbO}$-based non-ferrous slag saturated in spinel [J]. Journal of the European Ceramic Society, 2015, 35: 347-355.

[30] DE WILDE E., BELLEMANS I., ZHENG L., CAMPFORTS M., GUO M., BLANPAIN B., MOELANS NELE, VERBEKEN KIM. Origin and sedimentation characteristics of sticking copper droplets to spinel solids in pyrometallurgical slags - Submitted [J]. Metallurgical and Materials Transactions B, 2015,

[31] BELLEMANS I., DE WILDE E., MOELANS N., VERBEKEN K. Phase field modelling of the attachement of metallic droplets to solid particles in liquid slags: influence of particle characteristics [J]. Acta Materialia, 2015, In press 